\title{
PLURALISTIC FIQH BASED ON PERSPECTIVE OF IMAM AL-SYA'RANI IN THE BOOK OF AL-MIZAN AL-KUBRA
}

\author{
Ahmad Taufik Hidayat ${ }^{1} \&$ Alfurqan ${ }^{2}$ \\ ${ }^{1}$ Faculty of Adab \& Humaniora Universitas Islam Negeri Imam Bonjol Padang \\ ${ }^{2}$ Faculty of Social Sciences, Universitas Negeri Padang, Indonesia

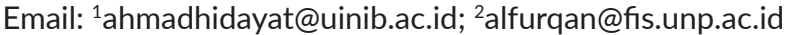

\begin{abstract}
This research was intended to examine al-Syarani main thoughts on the diversity of legal schools as outlined in his al-Mizân al-Kubrâ work along with the context and challenges historically which in many cases gave rise to ikhtilaf (differences of opinion) in Fikih, as well as an overview in the legal context as a means of social transformation. The method used in this study was library research, both primary and secondary. Primary sources consisted of the works of al-Syarani (especially al-Mizan al-Kubra) with more emphasis on the content analysis. In detail, the problem is formulated in some questions; (1) what is the socio-historical situation (political, socioeconomic, intellectual, and religious traditions) behind the formation of al-Sya'rani ideas about Fikih pluralistic?, (2) what is the construction or pattern of al-Syarani thought regarding pluralistic Fikih?, (3) what is the position of al-Syarani thought in the perspective of law as one of the means of social transformation? As a result of this discussion, al-Syarani seeks to provide a new orientation in legal thinking in a direction that is closer to the demands of a real and pluralistic reality of life. The idea is then outlined in four main points of view which include: (1) Justification of three episteme systems (2) The use of pragmatism principles in the application of the law, Legitimacy of legal changes in line with the development of the situation (3) His views on the necessity of ijtihâd and prohibition of taqlîd in practice Sharia law.
\end{abstract}

Keywords: Pluralistic; Imam al-Sya'rani; manuscript al-Mizan al-Kubra

Abstrak: Penelitian ini dimaksudkan untuk mengkaji pokok-pokok pikiran al-Sya'rani atas fakta keragaman mazhab hukum sebagaimana yang dituangkan dalam karyanya al-Mizân al-Kubrâ beserta konteks dan tantangan historisnya yang dalam banyak hal memunculkan ikhtilaf (perbedaan pendapat) dalam fikih, serta sebuah tinjauan dalam konteks hukum sebagai sarana transformasi sosial. Metode yang digunakan dalam penelitian ini telaah pustaka (library research) baik yang primer maupun sekunder. Sumber primer terdiri atas karya-karya alSyårani (khususnya al-Mizan al-Kubra) dengan lebih mengutamakan sisi analisis isinya (content analysis). Untuk mengkajinya secara lebih rinci, masalah tersebut dirumuskan dalam sejumlah pertanyaan; (1) Bagaimana situasi sosio-historis (politik, sosio-ekonomi, tradisi intelektual dan keagamaan) yang melatarbelakangi terbentuknya ideide al-Syärani tentang fikih pluralistik? (2) Bagaimana konstruksi atau pola pemikiran al-Syảrani mengenai fikih pluralistik? (3) Bagaimana posisi pemikiran al-Syảrani tersebut dalam perspektif hukum sebagai salah satu sarana transformasi sosial. Hasil dari pembahasan ini, al-Syałrani berupaya memberikan orientasi baru dalam pemikiran hukum ke arah yang lebih dekat dengan tuntutan realitas kehidupan yang sesungguhnya dan bersifat pluralistik. Idenya tersebut kemudian dituangkan dalam tiga pokok pandangannya yang meliputi: (1) Justifikasi tiga sistem episteme (2) Penggunaan prinsip pragmatisme dalam penerapan hukum, Legitimasi perubahan hukum sejalan dengan perkembangan situasi (3) Pandangannya tentang keharusan ijtihâd dan larangan taqlî̀ dalam pengamalan hukum syariat.

Kata kunci: Pluralistik; Imam al-Syårani; naskah al-Mizan al-Kubra 


\section{Introduction}

For Muslims, Islamic law in technical terms is called Fiqh. Even though it is quite popular, it is not a convention that is accepted by all Islamic law experts. Some scholars say that Jurisprudence is Islamic jurisprudence ${ }^{l}$ occupies a very central position, because the rules which cover all aspects of their lives. Therefore, what is simply called "Islamic law", would actually be more appropriate if it is appreciated as a whole of the religious life system in Islam itself. As a rule, any discussion about the law of Islam always involves the most basic religious beliefs and attitudes of Muslims. This is because in Islamic teachings, divine orders manifest themselves in a concrete way in the form of a certain set of laws and not just general moral commands that are more abstract. $^{2}$

As a religion, Islam is believed by its adherents to have absolute and final truth values, but Jurisprudence as a concept of its application cannot be separated from the influence of changing times and mutually influencing the situation. ${ }^{3}$ The scholars

1 The view that considers the notion of Islamic law as a "translation" of the term Fiqh as it is intended to be used as a whole here, although quite popular, is not a convention that is accepted by all scholars of Islamic law. Noel J. Coulson, for example, in one of his works defines Fiqh as Islamic jurisprudence while Anderson sees it as a Qanun or state law. Some scholars also distinguish the meaning of Islamic law in the context of its general principles (Shar'ia) and in the context of its concepts. technical application (Fiqh). N. J. Coulson, $A$ history of Islamic Law, (Aldine Transaction, 2011), p.332.

2 JND Anderson, Islamic Law in Modern World (New York: University Press, 1959), p. 4; Bandingkan juga dengan D.B. Mc Donald, Moslem Theology Jurisprudence and Constitutional Theories, (New York University Press, 1907); and Nasser, Ideals and Realities of Islam, (London: George and Allen Unwin, 1966), p. 105-6.

3 Ahmad Chatib, Hukum Islam dan Perubahan Masyarakat, (Jakarta: Intermasa, 1980), p. 357-71. Lihat juga Yusuf Qaradhawi, Ijtihad Kontemporer Kode Etika dan Berbagai Penyimpangannya, terj. Abu Barzani, (Surabaya: Risalah Gusti, 1995), p 7-10. concluded that these religious norms through the process of ijtihad from religious sources (al-masadir al-diniyyah), which in reality are textually different from one another. From various information groups, the formulation of the norms of life is then drawn using certain methodologies, approaches, and interpretations (turiiq al-istinbat). ${ }^{4}$ These interpretive rules are known as Usul al-fiqh. ${ }^{5}$

As a result of interpretations that continue to evolve from time to time, the historical environment and socio-cultural atmosphere surrounding individual interpreters are very influential, both on the choice of reference, the method used and the approach pattern used and to the conclusion of ijtihad. The results of this interpretation have now become the enormous intellectual treasury of Islamic law (tharwa fikihiyyah). Most of them have been well preserved to date in the works of Jurisprudence in various schools of law.

\section{Research Method}

This study is based on a study of libraries (library research), both primary and secondary. The primary source consists of the works of al-Sya'rani (especially al-Mizan al-Kubra) with a more emphasis on the side of content analysis. Meanwhile, secondary sources consist of various scientific publications and other scholarly works on ikhtilâf al-fuqaha'.

4 These interpretive rules are known as Usūl alfiqh. For a broad description of the theories of legal interpretation in Islam, see al-Yasa Abu Bakr, "Some Jurisprudence Theories and Their Applications" in Tjun Sudjarman (ed.), Hukum Islam di Indonesia Pemikiran dan Praktek (Bandung: Rosdakarya, 1994), p. 173- 208. Juga Muhammad Hashim Kamali, Prinsip dan Teoriteori Hukum Islam, translated by Noorhaidi (Yogyakarta: Pustaka Pelajar, 1996), in chapter IV and V, p. 109-88.

5 Kutbuddin Aibak, "Penalaran Istislahi Sebagai Metode Pembaharuan Hukum Islam", Al-Manahij: Jurnal Kajian Hukum Islam, Vol. 7, No. 2, 2016, doi: 10.24090/ mnh.v7i2.2013.pp169-182. 
The methods used in this research include descriptive, historical, and synthesis analysis methods.

This is qualitative research, so the strategy and approach is inductive-conceptualization. The data analysis is tentative, so that as long as the research is ongoing there is always the possibility of making adjustments in the discussion frame and also improving the problem mapping frame, in line with the possibility of new findings that might encourage the modification.

\section{The Urgency of Plurality of Fiqh}

The wide spectrum of ikhtilaf (differences between the schools of Fiqh), as a whole, is a blessing for people's lives and there are many alternative ways to practice religious teachings that they can choose according to the conditions of each individual ${ }^{6}$. The legitimacy of this is often quoted from the Prophet's hadith: "ikhtilaf 'ala ummati rahmah" (differences of opinion among my people are mercy) ${ }^{7}$. However, the authenticity of the hadith is from a certain point of view controversial $^{8}$.

However, in reality, the various legal concepts, on the other hand, have created separate dilemmas for the lives of Muslims,

\footnotetext{
${ }^{6}$ There are two poles of views in addressing this summary fact. The first group rejected the possibility of ikhtilaf because they saw ikhtilaf as bid'ah and became the cause of the decline of the people. Meanwhile, the second view actually sees it as concrete evidence that even though Islam stands firmly on the basis of absolute truth, it still provides wide space for the development of thought.

7 This is stated by al-Tabari in Ikhtilaf al-Fuqaha (Beirut: Dar al-Kutub al-Ilmiyya, tt.), p. 6

${ }^{8}$ Syekh Nasiruddin al-Albani, for example, strongly rejected the validity of this hadith. Quoting Allamah Subky, regarding the hadith he said "Sanad da'if and maudu'nya are not found let alone valid ones". see Mun'im A Sirry, "Ke Arah Rekonstruksi Tradisi Ikhtilaf", Jurnal Ulumul Quran, vol. V, no. 4, 2004, p. 59.
}

both individually and collectively from the past until now. ${ }^{9}$ The issue of Law schools which became one of the historical evidence of the brilliant intellectual activity of the early generations of Muslims (especially the 1st to 3rd centuries of Hijriah), it turns out that lately, it has caused many unwanted effects and among the most serious consequences is the disruption of the spirit of solidarity and ukhuwwah among them., as well as the emergence of various difficulties in formulating appropriate forms of response to modernity by sticking to the fundamental values of religious teachings that they believe in.

Many factors influenced this, but among the most dominant was the excessive admiration for the founding fathers and school leaders, who slowly but surely eroded the criticisms of the scholars and tended to limit their intellectual activities to their efforts. collect, understand, develop, defend, record and then disseminate the thoughts of the priests of that school. ${ }^{10}$

The increase in the spirit of sectarian fanaticism is directly proportional to the tendency to weaken creativity and the spirit of innovation to create something new. Another negative implication is the reduced intensity of the flow of healthy intellectual dialogue across schools. So it is natural that over the last five centuries, even though the world has experienced very dramatic historical developments in various fields, the thinking of the scholars has hardly departed from the issues of "margins" which have actually

\footnotetext{
${ }^{9}$ Among the academic problems regarding this matter, among others, can be seen at Ubaid al-Haqq "Islamic Revival: The Challenge of Change" in Taufiq Abdullah. (ed) Tradisi dan Kebangkitan Islam di Asia Tenggara, (Jakarta: LP3ES, 2008), p. 460-83. See Anderson, Islamic Law..., p. 81-100

${ }_{10}$ Mun'im A.Sirry, Sejarah Fikih Islam, (Surabaya: Risalah Gusti, 2005), p 132.
} 
been thoroughly discussed by previous scholars. Until now, there are still many Jurisprudence scholars who still like to spend their intellectual energy discussing various classical legal cases that have been the subject of debate for centuries since the Middle Ages. In the context of social life, such patterns of intellectual attitudes naturally fertilize the "seeds of conservatism" in all areas of life and foster "the spirit of sectarian fanaticism" which has been proven to often destabilize the unity of the ummah.

Thus, even though there have actually been various legal concepts as a result of the development of thought in the past, most people still cannot get significant benefits, because culturally most of them are already educated to a priori affiliate themselves (and only want to relate ) with a particular school of thought or school of thought. What Coulson describes as a form of conflict and tension between the existing Islamic legal concepts, namely between the principles of unity (unity) and diversity (diversity), remains unsolved. ${ }^{11}$

In response to this situation, a number of scholars attempted to make breakthroughs with cross-sectional legal studies, comparative studies (muqaranah al-mazahib) and tarjîh. Ibn Qudamah (d. 620 H / 1223), a prominent Hanbali scholar, was one of a number of important pioneers. Through his magnum opus, al-Mughni al-Muhtaj (Ibn Qudamah, 1983), he made a critical study of various views of Jurisprudence to be compared with the traditional views that developed within the Hambali school of thought. This step was followed by a number of scholars in the following periods. ${ }^{12}$ This effort was, of course,

\footnotetext{
${ }^{11}$ N. J. Coulson, A History of Islamic Law, p.334.

12 N. J. Coulson, Conflicts and Tension in Islamic Jurisprudence, (Book Review, Archív Orientální, 41, 2003), p. 134.
}

an important and courageous step in trying to break the ice at the time. However, because the comparative study and tarjih are carried out individually based on reference sources, methodologies and their own approaches, while their followers are also not accustomed to appreciating various opinions, from there a number of "new schools" (schools of tarjih results are born again). which vary and have no small influence in the escalation of the growth of sectarian primordialism, especially in the common people.

Here is the problem, that at the level of application, the validity of a concept of Islamic law is not sufficient if it is only approached from the side of the tariqa al-istinbat, but requires more comprehensive approaches, which include: (1) comparative-critical analysis. in terms of methods and approaches in his istinbat (2) epistemological studies, especially regarding sources of knowledge regarding Islamic law that can be considered valid, (3) studies of the aspects of moral philosophy behind the practice of Islamic law and religious obsessions of people people of faith, (4) other approaches in the form of critical analysis from a historical and sociocultural perspective. ${ }^{13}$

\section{Biography of Imam Al-Sya'rani}

Imam Al-Sya'rani was born on the 27 th of Ramadan $898 \mathrm{H} / 1493 \mathrm{AD}$ in the village of Qalqasyandah, the village of his grandfather from the mother line. His real name is, Abd al-Wahhab ibn Ahmad ibn Ali ibn Ahmad ibn Ali ibn Muhammad ibn Zaufan ibn Shaykh Musa the title of Abu Umran ibn Sultan Ahmad ibn Sultan Fasyin ibn Sultan Mahya ibn Sultan Zaufan ibn Sultan Rayyan ibn Sultan Muhammad ibn Musa ibn Sayyid

\footnotetext{
${ }^{13}$ N. J. Coulson, Conflicts and Tension..., p. 182-183.
} 
Muhammad bin Hanafiah ibn Imam, Ali ibn Abi Talib Radiyallahuanhum. Imam AlSya'rani memorized al-Quran and several eyes from childhood, Abu Syuja 'and alAjrumiyah. Learned these two eyes from his brother who is also a scholar. In the tenth year of his life, he and the scholars studied nahwu and others. Has the characters of zuhud, qana'ah, tawakkal, and far from the luxury of life, and since he was young he has lived the world of Sufism. ${ }^{14}$

Since childhood, he had been orphaned. For that he was raised by his brother Shaykh Abd al-Qadir, an alim and Sufi. And since he was young, the name Imam Sya'rani began to be known and gained wide acceptance from the community, having recitation in mosques and madrasas. ${ }^{15}$ While in Cairo he studied with the best scholars at that time; Imam Jalaluddin as-Suyuti, Zakariya alAnsari, Nasiruddin al-Luqqani, ar-Ramli, al-Samnudi, Shaykh Nuruddin al-Tarabulisi, Shaykh Syihabuddin asy-Sya'labi, Shaykh Syamsuddin al-Qurra 'al-Kabir, all three Hanafi, Shaykh Ali alKhawwas al-Barlisi, who according to Imam Sya'rani he is illiterate. There he also studied Sufism, fiqh, jurisprudence, hadith, interpretation, and language ${ }^{16}$, memorizing the book al-Minhaj by Imam Nawawi, Alfiah ibn Malik, Taudih and Qawa'id ibn Hisyam, Jam'u al-Jawami', Alfiah al-Iraqi, al-Miftah summary, works of the Imam Syatibi, as well as summary books. He also did not forget to memorize a summary of the book ar-Raudah, a book that collects many opinions in the Shafi'i school of thought. Besides the Syafi'i school he also

\footnotetext{
${ }^{14}$ Mahmud Ahmad Hasyim, al-Imam al-Sya'rani, (Kairo: Maktab Islamiyah, 2001), h. 16.

${ }^{15}$ Mahmud Ahmad Hasyim, al-Imam al-Sya'rani, h. 75.

${ }^{16}$ Mahmud Ahmad Hasyim, al-Imam al-Sya'rani, h. 20.
}

studied 3 other major schools. ${ }^{17}$ Under the guidance of Imam Zakariya al-Ansari, Imam Sya'rani read the books of fiqh, ushul fiqh, and tasawuf. Such as: Raudhah, Minhaj, Tafsir alQur'an al-Azhim by Imam Baidawi, Hasyiah Tibbi on al-Kasyaf's interpretation, Hasyiah Jalaluddin as-Suyuti Jam'u al-Jawami ', Syarah al-Bukhari by Imam Ibn Hajar, al- Kirmani, al-Aini, al-Barmawi, and many others. Imam Zakariya wrote quite a number of articles and was widely distributed, and at that time he was also the great mufti in Egypt. ${ }^{18}$

The depth and breadth of Imam Sya'rani's knowledge can also be seen in the book alMizan al-Kubra. Before writing this book, he had studied various books which were classified into three parts, ${ }^{19}$ namely:

1. The books that have been memorized by heart, and have been recited to the scholars.

2. The books that have been given sharah verbally in front of the scholars repeatedly in the context of tashih, he mentioned the second part of the book in al-mizan approximately 76 book titles, of which there are volumes and read to the scholars repeatedly, such as: Syarh al-Minhaj, written by Sheikh Jalaluddin asSuyuti which was recited to many sheikhs including Ibn Qadi Ajlum by examining his syarahs in Egypt 10 times.

3. The books are reviewed by themselves, then asked questions that are difficult to the scholars. The books in this section reach approximately 125 book titles, covering books in the fields of fiqh Syafi'iyah, Malikiyah, Hanabilah, Hanafiah, in the field of language, hadith, fatwas, and

\footnotetext{
${ }^{17}$ Mahmud Ahmad Hasyim, al-Imam al-Sya'rani, h. 46.

18 Mahmud Ahmad Hasyim, al-Imam al-Syárani, (Kairo: Maktab Islamiyah, 2001), p. 123.

19 Imam Sya'rani, al-Mîzân al-Kubrâ, (Singapura: Mathba"ah Sulaiman Mar"i, t.th), p. 75-79.
} 
qawaid. Such as: Tafsiral-Baghawi which he studied 3 times, Jalalain's interpretation 30 times, Jalal al-Mahalli's Syarah Minhaj 10 times and others.

Of the many books he has read, it can be said that he really has mastered the various thoughts of the scholars across schools of thought, which led him to perform ijtihad to integrate these various opinions in his various books.

Imam Syarani likes to read the works of scholars, he is also very active and productive in producing various works in various disciplines, ranging from the science of monotheism and faith, jurisprudence, hadith science, ushul fiqh and qawaid, knowledge, biographies of scholars, Sufism, medicine and etc. For example the books Mukhtashar I'tiqad al-Baihaqi, Kasyf al-Ghummah, al-Badru alMunir Fi Ahadis al-Basyir, Thabaqat al-Kubra, Lawaqih al-Anwar al-Qudsiyah, and others.

In Manaqib al-Qubra as conveyed by Muhammad Muhyiddin Abi al-Uns, Imam Sya'rani has written approximately 300 books related to the science of sharia and its tools. ${ }^{20}$ Even in some of his works, Imam Sya'rani has a specificity where none of the previous scholars wrote it, and his tasawuf works can be pursued and studied by anyone who studies them without needing a teacher (shaykh). ${ }^{21}$ As well as Imam Sya'rani whom Allah met with expert scholars, he also had several students who studied with him, including: Abdur Rauf al-Munawi asy-Syafi'I, Abdur Rahman ibn Abd al-Wahhab asy-Sya'rani, Syihabuddin Ahmad al-Kalaby al-Maliki, Muhammad Hijazy ibn Abdullah al-Qalqasyandi. ${ }^{22}$

\footnotetext{
${ }^{20}$ Imam Sya'rani, al-Mîzân al-Kubrâ, p. 67.

${ }^{21}$ Muhyuddin Abi al-Uns, al-Manâqib al-Kubrâ. p. 71.

${ }^{22}$ Muhyuddin Abi al-Uns, al-Manâqib al-Kubrâ, p.
} 90-93

\section{The Reality of the Diversity of Understanding in Fiqh}

In the reality of life that always appears various problems that require legal answers, it is often that a particular legal issue gets more than one or even very various opinions as a solution or answer regarding the legal provision. If the opinions are identical or in harmony, perhaps it does not matter. But how are the solutions different? As a result, in a legal issue, where there are various legal opinions or different fatwas, it often raises trush claims from certain groups that can trigger conflict in society.

The attitude of neglect in dealing with differences or various fatwas so far has been a factor causing social disharmony among Muslims in various places. In addressing the various kinds of fatwas of ulama in Islamic law, it is necessary to develop new thoughts as an alternative solution.

In a practical level, fiqh is a science that is flexible and dynamic in accordance with its object and context. This fact can be seen from the many differences in views or opinions between fiqh scholars. This difference does not only arise from those with different schools of thought, but also within the same school as adherents of the same sect. ${ }^{23}$

Therefore, differences in views or opinions on the issue of fiqh are a reality and inevitably occur, because these differences depart from different perspectives on interpretation and understanding of sources, all of which are essentially from the texts of the Al-Qur'an and the Hadith.

The application of shari'a rules is not sufficiently understood as an effort to make

23 R. Sugara, Reinterpretasi Konsep Bid'ah Dan Fleksibilitas Hukum Islam Menurut Hasyim Asyari, (Jakarta: Asy-Syari'ah, 2019). 
texts (both literally contained in sharia texts and literature by mujtahid ulama) into social realities, but rather as a result of the eternal process of "interactive dialogue", the result being the point of elastic balance of the force of attraction between the demands contained in the text and social reality; also between what is considered ideal and what can actually be strived for, which is expected to provide the best answers to existing social problems, as well as produce a positive impact that is truly felt by the community.

Different situations and conditions are very important in determining the style of thought and life of the community, including in the religious aspect. Differences in the characteristics of religious life between people in mountainous areas with cool air and people living in hot coastal areas. The level of difficulty in praying for example, differs between areas that have an abundant supply of water and areas that are difficult to get clean water. Such natural conditions cause differences in the level of difficulty faced by people in living life, which in turn also determines the diversity of religions in the area.

The diversity of sociological characteristics and the stages of social development also greatly affects the atmosphere of community life and the complexity of problems in the political, economic, social, cultural and scientific development fields. The difference between the life of rural and urban communities, between agrarian and industrial societies, between the poor and the rich, between majority Muslims and minorities, between independent nations and colonized nations and between communities with strong written traditions and those with stronger traditions oral. These differences will also affect the style of thought and practice of religious teachings between community groups. ${ }^{24}$

The influence of ulama who carry or spread religion also greatly influences the understanding and pattern of diversity of the society in which religious teachings are spread. This explains why the Islamic atmosphere in certain regions tends to use certain schools of thought. Differences in psychological maturity, social and spiritual visions between individuals, which are influenced by many factors such as age, gender, completeness and physical abilities, intellectuality, level of economic welfare, social position, educational background, family environment, childhood experiences and other special experiences. This has a profound influence on the legal conclusions that result from istinbâţ activity on the sources of sharia. ${ }^{25}$

In the stretch of the course of Islamic history, various schools of law reflect the reality of plurality that cannot be denied. Likewise, various fatwas on a certain legal issue have emerged since the time of the Companions, then the time of Tabi'in and their followers and the climax was in the era of the Imam mazahab and so on until now. Various responses have emerged from among the scholars regarding the reality of the various fatwas that have emerged, including from Imam al-Sya'rani.

${ }^{24}$ Mutohharun Jinan, "Penetrasi Islam Puritan Di Pedesaan, Kajian tentang Pola Kepengikutan Warga Majlis Tafsir AlQuran”, Profetika Jurnal Studi Islam, Vol. 14,No. 2, Desember 2013, doi: https://doi.org/10.23917/ profetika.v14i2.2011

${ }^{25}$ M. Arif, "Islam, Kearifan Lokal, dan Kontekstualisasi Pendidikan: Kelenturan, Signifikansi, dan Implikasi Edukatifnya", Al-Tahrir: Jurnal Pemikiran Islam, Vol. 15, No.1, 2015, p. 173. 


\section{Imam Al-Sya'rani's thoughts on the plurality of Fiqh}

Imam Al-Sya'rani (898-973 H / 1492$1565)$ is one of the small number of scholars who are known to have tried to appreciate all of the above at once and then put it in his theses comprehensively. To support his theses, he also included layers of arguments, both from the texts of the Al-Qur'an, Sunnah, historical explanations and rational elaborations.

For Imam Al-Sya'rani, the diversity of thoughts and the practice of Islamic law in people's lives is not only a historical reality (das Sein) which must be forced to accept, but from an ethical point of view it is also a moral imperative (das Sollen). Of course in order for the appreciation of the work to be carried out properly, all the social visions and ideas contained in it must be seen fairly according to the stages of intellectual development, challenges and the socio-historical situation of society at that time and only then put them in perspective of the problems faced by the community. humans in the present. ${ }^{26}$

Compared to the patterns of handling ikhtilâf developed by other scholars, among the scholars who have discussed this issue (the question of changing the rule of law in line with the development of the situation) is Ibn al-Qayyim (d. 751/1350). both those who lived before and after it, the theory of al-Syarani has distinctive important aspects: First, there is an attempt to combine an ethical perspective with a legality approach (between syariat and haqiqat) in developing the theory and application of Islamic law; and also a combination of epistemological approaches

${ }^{26}$ Zulkifli Hasan, "Yusuf al-Qaradawi dan Sumbangan Pemikirannya", Global Journal Al-Thaqafah, Vol. 3, No. 1, 2013, p. 14, https://doi.org/10.7187/GJAT332013.03.01 between tradition, ratio (reason) and kasyf (intuition) on the other.

Second, the concept is very accommodating to the dynamics of people's lives. For al-Sya'rani, the principle of fiqh historicity is something that must fundamentally be accepted. Therefore, the meaning of Islamic law should not be limited to what is explicitly stated in the Al-Qur'an and Sunnah (ma shabidat lahu al-shari'a sariban) or the thoughts that have been developed by the salaf al-salihin of the early generations (companions of the Prophet and tabi'in), but also includes all intellectual products of the ummah throughout history that are in line with the universal messages of the Shari'a, even though the Prophet never stated explicitly or did it himself (wa in lam yusarrih bihi al-shari).

Third, the affirmation of his belief in the truth (as well as appreciation) for the conclusions of all mujtahidin scholars, especially the four main schools of thought that have continued to develop until now. According to him, all the results of the ijtihad of the mujtahidin ulama figures are not only true and acceptable in the context of their theoretical truth entity, but at the level of application they are also at an equal position, as long as the arguments meet the requirements to be accepted.

The anxiety of al-Sya'rani as a faqib in seeing the faqih's way of thinking in response to the needs of the mainstream society, is seen from several aspects; first; the approach used by the faqih in understanding sharia tends to be rigid and standardized. Al-Sya'rani's thought tends to be compromise, for example his attitude towards conflicting arguments, using the terms azimah and rukhsah to take steps to resolve. The terms azimah and rukhsah are actually one of the discussions in ushul fiqh ${ }^{27}$

\footnotetext{
${ }^{27}$ According to Abdul Wahhab Khallaf rukshah is the
} 
related to the division of wad'i laws, but not for the settlement of ta'arud al-adillah.

Besides using the terms azimah and rukhsah in his compromise model, al-Sya'rani uses another term with the same meaning, namely tasydid for something categorized as heavy, while rukhsah for something that is categorized as light (takhfif). Second; doctrinal and ideological approaches in developing legal concepts without considering the implications and needs in responding to society's problems. Third, there is a tendency to give authorization to certain scholars in determining laws in all matters, even on technical matters so that this condition can numb the sense of morality and intellectual society in the ability to distinguish between Haq and falsehood. Fourth, legal products that are born tend to worship the truth are considered to have absolute truth, so that there is no gap of opinion, even though the problem decided is zhanni. For example, the opinion of the scholars who oblige the taklid of a muqallid or layman whose scientific position is limited and is unable to perform legal istinbat and perform ijtihad while still providing freedom for them to practice other schools of thought in order to avoid fanaticism. ${ }^{28}$ For Imam Sya'rani changing schools is a possibility, and does not blame people who move from one mazhab to another. ${ }^{29}$

desire of law that has been declared by Allah for mukkallaf in certain circumstances which are in accordance with that desire. in general from the beginning which is not limited to certain circumstances. Abdul Wahhab Khallaf, Ushul Figh, p. 167.

28 Said Ramadhan al-Buthi, Alla Mazhabiyyah Akhtar Bid'at Tuhaddidu al-Syari'ah al-Islamiyyah, terj. Anas Tohir Sjamsuddin, Bebas Mazhab Membahayakan Syariat Islam, (Surabaya: PT Bina Ilmu, 1983), Cet. ke- 2, p. 63

${ }^{29}$ Ahmed Fekry Ibrahim, "Al-Sharänïs Response to Legal Purism, Islamic Law and Society", Brill, Vol. 20, Issues 1-2, 2013. p. 130. doi: 10.1163/15685195-0004A0004
Another dimension of al-Sya'rani's orientation is that apart from being based on religious sources, legal thinking must always be linked together with the complexities of life's problems in the spirit of finding solutions. Therefore, the development of the legal concept must be accompanied by careful calculation of the implications that will arise from the application of the rule of law, both for the person concerned and for the citizen in general.

Another thing that can be implicitly identified from al-Sya'rani's thought is the introduction of a kind of pragmatism principle in determining the choice of legal concepts to be applied. Based on these principles, in order to assess the legal concept that will be carried out or applied in the life of a plural society, first of all, it must go through several stages of evaluation.

From a theoretical point of view, there is a sound validity of the bill based on compliance with the source (proposition) and general principles of Sharia law. This stage can also be referred to as the proposition verification stage, namely the steps to confirm whether the legal concept has sufficient arguments from the theoretical study of sharia, regardless of the analysis method and the approach pattern used in concluding.

In this context, al-Sya'rani asserted that his position was different from that of most jurists. According to him, the truth of fiqh at this level is pluralistic and tiered (consisting of several alternatives based on the principles of takhff and tashdid), which is theoretical (only at the level of intellectual construction and has not bound anyone to practice it). Al-Sya'rani thinks at this level it is no longer pluralism, but has been included in the category of parallelism. Parallelism is understood as a flow in theory of thought where a theory of 
interpretation or a special comparative method that seeks to find similarities in the formulation of thoughts between two opinions that have different contexts, emphases, directions of thought and solutions but have characteristics that are in line, congruent or parallel. In other words the view that all schools of thought and schools of thought, though different, tortuous and seemingly contradictory, have a point of alignment which allows them to meet one another at the time limit of the human pilgrimage.

The application of any rule of law needs to prioritize achieving more basic and universal legal objectives, while legalistic-formalistic technical aspects (no matter which version of the school they wish to use) should be placed on secondary priority. That is, all the different views of the law must be accepted without exception, all argue that a patternbased approach is sufficiently ubiquitous, and tarjih is not necessary from the start to select one idea that is assumed to be true for all (assuming the other is forever). Apart from that, the criteria in determining which version of the legal concept is considered accurate are also closely related to methodological choices, which still have debatable sides. Thus, the formalities of Sharia teachings can be applied flexibly according to situations and conditions, while the achievement of broader moral goals is always a higher priority.

\section{Conclusion}

Al-Sya'rani seeks to provide a new orientation in legal thought towards a direction that is closer to the demands of the real and pluralistic realities of life. The idea is then stated in three main points of view which include: (a) Justification of three episteme systems (b) The use of pragmatism principles in the application of law, (c) The legitimacy of legal changes in line with developments in the situation. His view is about the necessity of ijtihâd and the prohibition of taqlìd in practicing sharia law.

His book Mizan al-Kubra provides solutions to jurisprudence problems to cover all opinions of classical scholars regarding various existing figh problems, ranging from issues of worship, muamalah, munakah, or jinayah. The other side of al-Sya'rani's thoughts which he stated in his book, is the mapping of the opinions of the scholars who are rather strict (mutasyaddid) in issuing fatwas against various cases of fiqh that exist with those who are lighter (mutasahhil). This is only intended to provide a more diverse presentation for Muslims in doing charity according to the opinions of the scholars they like.

Al-Sya'rani, who was always compromising in seeing the differences in opinion among the scholars. Respect all the opinions of the scholars, however weak they are. Because after all, what they claim cannot be separated from the methodology and argument. The conclusion is, as long as the opinion is still based on the methodological and systematic argument and istidlal (way of reasoning), there is no room for anyone to ignore or even blame it.

\section{References}

Ahmad, A. Alfurqan \& Diyanto, R. Manuskrip Ijazah Dan Silsilah Tarekat: Legitimasi Mursyid Tarekat Naqsyabandiyah dan Syattariyah di Minangkabau. Padang: Hadharah, 2019.

Aibak, Kutbuddin. "Penalaran Istislahi Sebagai Metode Pembaharuan Hukum Islam”, Al-Manahij: Jurnal Kajian Hukum Islam. Vol. 7, No. 2, 2016, doi : 10.24090/mnh. v7i2.2013.pp169-182. 
Alfurqan, A., \& Harmonedi, H. "Pandangan Islam Terhadap Manusia: Terminologi Manusia dan Konsep Fitrah serta Implikasinya dengan Pendidikan". Journal Educative: Journal of Educational Studies, Vol. 2, No. 2, 2017.

Al-Sya'rani. Mizan al-Kubra, Beirut:Dar'alKitab al-arabiyah, t.th.

Al-Tabari. Ikhtilaf al-Fuqaha'Beirut: Dar alKutub al-Ilmiyyah, t.th.

Amin, M. Masyhur (ed.) Pengantar ke Arah Penelitian dan Pengembangan Ilmu Pengetahuan Agama. Yogyakarta: P3M IAIN Sunan Kalijaga, 2002.

Anderson, JND. Islamic Law in Modern World, New York: University Press, 1959.

Arif, M. "Islam, Kearifan Lokal dan Kontekstualisasi Pendidikan: Kelenturan, Signifikansi, dan Implikasi Edukatifnya”, Al-Tahrir: Jurnal Pemikiran Islam. 2015, doi: 10.21154/al-tahrir.v15i1.173.

Bahri, K. "Metode Kompromistik Imam Sya'rani Dalam Ta'arudh Al-Adillah Dan Implikasinya Terhadap Ijtihad Hukum Islam”. Journal Analytica Islamica, Vol. 4, No.1, 2015.

Bakar, al-Yasa Abu. "Beberapa Teori Penalaran Fikih dan Penerapannya "dalam Tjun Sudjarman (ed.), Hukum Islam di Indonesia Pemikiran dan Praktek, Bandung: Rosdakarya, 2004.

Buthi, Said Ramadhan al-. Alla Mazhabiyyah Akhtar Bid'at Tuhaddidu al-Syariah alIslamiyyah, terj. Anas Tohir Sjamsuddin, Bebas Mazhab Membahayakan Syariat Islam, Surabaya: PT Bina Ilmu, 2003.

Coulson, N. J. A History of Islamic Law, Aldine Transaction. 2011.

Donald, D.B. Mc. Moslem Theology Jurisprudence and Constitutional Theories, New York University Press, 1997.
Hasan, Zulkifli. "Yusuf al-Qaradawi dan Sumbangan Pemikirannya”, Global Journal Al-Thaqafah, Vol.3, No. 1,2013, doi: https:// doi.org/10.7187/GJAT332013.03.01

Huda, Miftahul. "Syari'ah, Fiqih dan Sebuah Perspektif tentang Tarjîh”, ISLAMICA Jurnal Studi, Vol. 5,No. 2, Januari 2014, doi: 10.15642/islamica.2011.5.2.220-233

Huda, M. "Epistemologi Tasawuf dalam Pemikiran Fikih Al-Sya rânî, ULUMUNA Journal of Islamic Studies, Vol. 14, No. 2, 2010, doi: https://doi.org/10.20414/ujis. v14i2.217

Hudson, L. "Reading Al-Sha'rani: The Sufi Genealogy of Islamic Modernism in Late Ottoman Damascus", Journal of Islamic Studies, Vol. 14, Issue 1, 2004, doi:org/10.1093/jis/15.1.39

Ibrahim, Ahmed Fikry. "Al-Sharänïs Response to Legal Purism, Islamic Law and Society", Brill, Vol. 20, Issues 1-2, 2013. doi: 10.1163/15685195-0004A0004.

Jinan, Mutohharun. "Penetrasi Islam Puritan Di Pedesaan, Kajian tentang Pola Kepengikutan Warga Majlis Tafsir AlQuran”, Profetika Jurnal Studi Islam, Vol. 14, No. 2, Desember 2013, doi: https://doi.org/10.23917/ profetika.v14i2.2011.

Kamali, Muhammad Hashim "Prinsip dan Teori-teori Hukum Islam”, terj Noorhaidi, Yogyakarta: Pustaka Pelajar, 2006.

Mun'im A Sirry, "Ke Arah Rekonstruksi Tradisi Ikhtilaf, Jurnal Ulumul Quran Jakarta: LSAF, Vol V, No. 4, 1994.

Nasser, Ideals and Realities of Islam, London: George and Allen Unwin, 1966.

Pagani, S. 'The meaning of the ikhtilaf almadhahib in 'Abd al-Wahhab al-Sha'rani's al-Mizan al-Kubra', Islamic Law and Society, 2004 a. 
Pagani, S. 'The Meaning of the Ikhtilâf Al-Madhâhib in 'Abd Al-wahhâb AlSha’rânîs Al-Mîzân Al-Kubrầ, Islamic Law and Society, 2004b. doi: 10.1163/ 156851904323178746.

Qaradawi, Y., Barzani, A., \& Hakiem, M. L. Ijtihad kontemporer: Kode Etik dan Berbagai Penyimpangan, Bandung: Risalah Gusti, 2000.

Qudamah, Ibn. Al-Mughni, Dar al-Kitab alArabi, 1983.
Nasser. Ideals and Realities of Islam, London: George and Allen Unwin, 1966.

Sugara, R."Reinterpretasi Konsep Bid'ah Dan Fleksibilitas Hukum Islam Menurut Hasyim Asy'ari”, Jurnal Asy-Syariah, 2019. doi: 10.15575/as.v19i1.4029.

Polívková, Z. Noel J. Coulson, Conflicts and Tension in Islamic Jurisprudence, (Book Review). Archív Orientální, 41, 2003.

Shomad, A. Hukum Islam: Penormaan Prinsip Syariah dalam Hukum Indonesia. Jakarta: Kencana, 2017. 